\title{
Restoraktiv Justice Policy in the Investigation of Children as Trafficking Actor
}

\author{
Ifahda Pratama Hapsari \\ Faculty of Law University of Muhammadiyah Gresik \\ Jln. Sumatra 101 Gresik Kota Baru, Gresik 61121, East Java \\ E-mail: ifa.zegeeg@gmail.com
}

Received: January 9, $2018 \quad$ Accepted: April 22, $2018 \quad$ Published: April 24, 2018

doi: 10.5296/jsss.v5i2.12450 URL: http://doi.org/10.5296/jsss.v5i2.12450

\begin{abstract}
A forced effort by the investigator of the child of investigation because the investigator can not rule out a perpetrator. Nevertheless, the maximum effort of handling child offenders in non-litigation cases is preferred by looking at the nature of the child and Non penal sanction is more appropriate for the child of the offender. Furthermore, the action that can be carried out by the investigator on the child of the Trafficking Trafficking in Law Number 11 Year 2012, to substitute for restitution restitution, and the return to the parent / guardian is a matter that is deemed appropriate, since the investigator has no authority to override the case, even in conduct investigations with more emphasis on prioritizing restorative justice rather than formal legalistic considerations.
\end{abstract}

Keywords: Investigation, Child and trafficking

\section{Background}

The State of the Republic of Indonesia is a constitutional state based on Pancasila and the 1945 Constitution of the State of the Republic of Indonesia, which upholds human rights and guarantees the rights of the citizens together with their positions in law and government, and is obliged to uphold the law and the Government that with no exception. The aim of the State of Indonesia is to create a just and prosperous society as stated in the preamble of the 1945 Constitution. In order to reach the just and prosperous society, the government has implemented development programs in all areas including in the field of law. Child Criminal Law covers all activities of examination and termination of cases concerning the interests of children in conflict with the law. The law can not be released from power. Power itself often comes from the authority (formal authority) or its power to a person or a party in a particular field. 
The issue of children in conflict with the law is very worrying. Act No. 3 of 1997 on the Court of the Child is no longer memandering in providing solutions to children facing the law. The role of law enforcement officers in the process of law enforcement of the Criminal Justice System that faces the trafficking case and the child who becomes the main perpetrator, is determined by the direction and the purpose of the results achieved in law enforcement itself. The Police of the Republic of Indonesia (Polri) is one of the protective law enforcers and protecting the society is obliged to maintain the law, justice and implementation of the Juvenile Justice System, as well as law and order of law.

In the framework of law enforcement in accordance with the Criminal Justice System, the Police is in charge of conducting criminal investigations carried out by Investigators / Investigators and the Criminal Investigation function of the Police as well as the operational functions of other Police who are authorized to conduct Investigations and to coordinate and supervise the children who become the perpetrators. The role of Police Investigators in the Criminal Justice System Being at the forefront and the early stages of the mechanism of the Juvenile Justice Process is the Preliminary Examination.

The rapid development of society's progress along with the rise of the rule of law, human rights, globalization of democratization, the decentralization of transparency and acutability laws has spawned new pradigms in view of the increasingly increasing objectives, functions, tasks, authorities and responsibilities of the Indonesian National Police Force and more oriented to the communities it serves.

Trafficking is one of the problems that the handling must be done all the components of the nation.It is necessary, because closely related to the image of the Indonesian nation in the eyes of the International. It is recognized that the handling of trafficking is not easy because the case of illegal human trafficking, abroad has occurred since many years of powerlessness to get decent work in the country itself and lack of facilities and infrastructure provided by the government that is inadequate and persuaded with salary which is high overseas is the cause of Indonesian labor migrants to overseas.

In Indonesia, there is no definite number of cases concerning trafficking, this is because trafficking is a dark trade which is the number of mena iceberg, meaning that cases raised in surface are much smaller than the facts that occur in the community. The number of cases that appear on the surface are only reported cases, whereas in reality, what actually happens is much greater.

Law Number 21 Year 2007 on the eradication of criminal acts of trafficking of persons enacted in 2007 has stipulated the threat of severe punishment and deterrent effect to traffickers, in addition to regulating the actions categorized as trafficking of the law so far has not succeeded in addressing child trafficking in particular, within the child criminal justice system itself. In fact, the law also does not provide witnesses to children who participate in the case and children in conflict with the law.

The entire peratran of the penal law is essentially a unit of punishment system as a condition of umm as well as a special provision. The system of punishment as a whole of the general norms of material criminal law (in the form of criminal penalty and criminal execution) applies also in the implementation of the criminal justice system of children, as long as it is 
not specified (lex specialis derogat legi generalis) in other words, various criminal justice systems apply also as a judicial system child crime.

Criminal acts committed by children are no different from criminal acts committed by adults, for example, a child has been able to commit a crime of trafficking in persons (or children) or even an adult he or she controls. However, different treatment interventions are generally between children and adults, but in fact different treatment also in children, because of differences in culture and society conditions, which also influence the differentiation of the use of minimum age and maximum in the positive law in a country. The existence of such distinctions reflects the variation in personal maturity and thinking of children in a country with in other countries. Determination of certain age limits used, mean taking the average size of personal maturity and thinking of children generally at that age, in certain countries.

That's why the topic of investigation of trafficking offenders is worth reviewing. The study focused on the issue of 1). What force can the investigator do to the child of the Trafficking offender in relation to the concept of restroactive justice ?2). What action can be done by the investigator against the child of the Trafficking Trafficker in Law Number.11 Year 2012?

This study is a normative law study conducted through literature study or library research, using conceptual approach, statute approach, and case approach .The legal materials used are primary, tertiary, and secondary legal materials.

\section{Discussion}

\section{A. Attempts That Can Be Conducted Investigators Against Trafficking Children In} Relation With Restroactive Justice

Trading activities / trafficking in Indonesia today are characterized by the emergence / number of localization or modern entertainment, for example: the number of homesteads that start in Dolly street is very famous and filled by young girls who prostitute themselves.

Human trafficking, especially children, is not only attributable to the complexity of the problem, but it can also be detached from foreign pressures or the issue of trafficking of people that is rife in relation to donation schemes to Indonesia.

Trafficking in Persons first appeared In 2000 when the United Nations General Assembly adopted protocols to prevent, suppress and punish human trafficking, especially children who added to the UN Convention (2000) to fight cross-border organizations, said that trafficking is:

Recruitment, transmission, persons with threats or use of Defamation or other forms of coercion, abduction, fraud, lies, or abuse of power or vulnerable positions or giving or receiving payments to obtain consent from someone in charge of others for the purpose of exploitation.

The concept of restorative justice in the process of settling the lawlessness that took place was carried out by bringing the victim and the perpetrator (suspect) together sitting in a meeting to get together to talk. In the meeting, the mediataor provides an opportunity for the perpetrator of the perpetrator to provide a clear picture of his or her actions. The perpetrator who exposes the party desperately expects the victim to be able to accept and understand the conditions and causes why the perpetrator committed a crime that caused the loss to the victim. 
According to Tony Marshall Restorative justice is a process whereby the parties involved in crime jointly solve problems relating to how to deal with the problem of post-crime and its consequences in the future. The main objective of restorative justice itself is the fairness of justice, especially for all parties involved and not just putting punishment forward.

Restoractive justice is an effort to support and implement Article 16 paragraph 3 of Law Number. Law No. 23 of 2002 concerning child protection, namely that the arrest, detention or imprisonment of children is only done if it is in accordance with applicable law and can only be done as a last resort.

The implementation of restorative justice in the Criminal Justice System is in line with the 2000 United Nations Declaration on Fundamental Principles on the Use of Restorative Justice Programs in Criminal Matters have advocated for the wider use of the restorative justice concept in a criminal justice system.

This is also confirmed by the Vienna Declaration on Crime and Justice in item 27 and item 28. The above is reiterated at the XI United Nations (UN) Congress on Crime Prevention and Criminal Justice held in Bangkok in 2005, where the congress was reaffirmed on Restorative Justice .This can be seen in point 32 of the Bangkok Declaration under the heading "Synergy and Response": "Strategic Alliance in the Prevention of Criminal and Criminal Justice". Basic Principles of Restorative Justice The implementation of restorative justice has the following basic principles:

1) The justice demanded is a recovery effort for the disadvantaged

2) Anyone involved and affected by a crime must have the opportunity to participate fully in following up

3) The government plays a role in creating public order, while the community builds and maintains peace.

In the commercial crime there are restorative justice characteristics, are:

1) Acknowledgment or guilty plea from the perpetrator

2) Approval of the victim to carry out the settlement outside the applicable criminal justice system

3) Approval from the police, as an institution that has a discretionary or from the prosecutor's office

4) Support local communities to implement solutions beyond the child criminal justice system

The main purpose of restoractive justice is the repair or compensation of the victims, the actor's recognition of the injury suffered by the community by his actions, the conciliation and reconciliation of the victim and the community to correct the unlawful acts by using awareness and conviction as the basis for improving the life of the community. Restoractive justice aims to restore the welfare of society, improve human as a member of society by confronting children as perpetrators in the form of accountability to the victim for his actions. In close connection with this restorative justice, Muladi reveals in detail the features of restoractive justice: 


\section{Macrothink}

Journal of Social Science Studies

ISSN 2329-9150

2018, Vol. 5, No. 2

1) Crime is defined as a violation as a person's offense against another person and is seen as a conflict

2) Focus attention on solving problems of liability and liability for the future

3) Qualitative properties are built on the basis of dialogue and negotiation

4) Restitution as a means of the parties, reconciliation and restoration is the main objective

5) The focus of attention is directed to the improvement of social wounds due to crime in which the offender's responsibility is formulated as the impact of understanding on his actions and directed to decide the best

In relation to the justice restorative mechanism, there are several mechanisms commonly applied in restorative justice as follows:

1) Victim offender mediation (mediation between victim and perpetrator)

2) Conferencing (meetings or discussions)

3) Circles (negotiate)

4) Victim assistance (victim assistance)

5) Ex-offencer assistance (mentoring ex-offenders)

6) Restitution (compensation)

7) Community service (community service)

Regarding the restorative justice model .In this model, John Braithwaite illustrates that the process of restorative justice goes hand in hand with measures of ability and prevention rather than walking concurrently in a restorative justice principle .Therefore, restorative justice fundamentals are reserved for perpetrators who really want an improvement so that it is possible to negotiate for restorative justice based on good faith, so that not all criminals can enter into this fashion to go to restorative justice based negotiations .

Restorative justice model . This model illustrates the alternative model. This model is more likely to lead to the satisfaction of the victim and not the punishment of the perpetrator. The approach undertaken in the criminal justice system in this model can first be carried out in the police as well as with the competent authorities, such as the prosecutor's office or the courts. The form of restoration is for example by way of the perpetrator of the crime to express his apology to the victim or other forms of improvement for the victim who is approved by the offender and the victim.

Inhibiting Factors Implementation of restorative justice

1) The substance of the law that has not accommodated the complete reestorative exercise

2) Law enforcers who have not implemented optimally existing regulations and are still rigid and legal culture / community participation that has not been optimal

3) Coordination between law enforcement officers and changing paradigm of law enforcement officers from retributive and restitutive justice approach to restorative justice has not been fully achieved. Furthermore, Under the provisions of Article 5 of the Criminal Justice System of the Child by The Beijing Rules published in Law No. 11 of 2012 aims at prioritizing Restoraktif's approach to justice which includes: 


\section{Macrothink}

Journal of Social Science Studies

ISSN 2329-9150

2018, Vol. 5, No. 2

1) The Criminal Justice System of the Child shall prioritize the restoractive justice approach

2) The child criminal justice system as referred to in paragraph 1 shall include:

a. Child criminal investigations and prosecutions are conducted in accordance with the provisions of law, unless otherwise provided in this law

b. The examination of the child in court is tried in a hearing of children residing in the public court

c. In the system of Child Criminal Justice as referred to in paragraph 2 sub-paragraph a and letter $b$ shall be attempted to diversify.

Implementation of Child Criminal Justice System is implemented based on Azas:

1) Protection

2) Non-discrimination

3) Best interests for children

4) Keeping in mind the child's opinion

5) Survival and growth of the child

6) Guidance and guidance of children proportional and

7) Deprivation of independence as a last resort.

The rights of the child in the criminal justice process are regulated by Article 3 of Law Number 11 Year 2012, among others:

a. Treated humans with attention to needs according to age

b. Obtain legal and other assistance effectively

c. Free from torture, punishment or other cruel treatment. Inhuman, and degrading degrees and dignity

d. Not arrested, detained or imprisoned except as a last resort and in the shortest possible time

e. Obtain fairness before an objective, impartial and objective court trial in public closed court.

Such provision is in line with the provisions of The Beijing Rules consideration shall be given whenever it is appropriate to deal with young legal offenders without the use of a formal tribunal by a competent authority referred to in Rule 14.1:

The police, the public prosecutor or other bodies dealing with child cases shall be authorized to decide the cases of the child shall be authorized to decide such cases, according to their discretion without the use of a formal preliminary examination in accordance with the criteria specified for the purpose in their respective legal systems and in accordance with the principles in these rules. Any diversion involving reference to community services or other services will require the consent of the child or his / her parent or guardian on the condition that the decision to refer to the case is subject to the review of the competent authority on the request. In order to facilitate the disposition / placement of discretion in childhood cases, efforts will be made to prepare for community programs such as supervision and temporary guidance of victim recovery and redress. 
The judicial system for children will prioritize the welfare of children and will ensure that any reaction to its violators and its law enforcement. Pursuant to Article 6 of the Act of purpose of the diversion:

a. Achieve peace between the victim and the child

b. Implementing children's cases outside the judicial process

c. Encourage the community to participate and

d. Infuse a sense of responsibility to the child.

In Article 1 number 8 of the Law on Child Criminal Justice System No. 11 of 2012 investigators are child investigators where investigators in this matter are affirmed in Article 7 paragraph 1:

Paragraph (1): At the level of investigation, prosecution and examination of a child's case in a district court must be attempted to diversify.

Paragraph (2): Diversi as referred to in paragraph (1) shall be conducted in the case of a prison sentence of under 7 (seven) years and not a crime

Police as the gateway of the child criminal justice system and the authorities first attribute the position of a child facing the law to segregate many places in the memory of the child facing the law. For the purpose of investigation, the police make arrests, detentions, searches in accordance with the Criminal Procedure Code. The investigation process of the Traffucking crime case can be likened to a series of entrances in which certain evaluation and assessment actions must be made before entering the door. In the case of child handling, Article 26 paragraph (1) states that the investigation of a child's case is conducted by an investigator determined by the Decree of the Chief of Police of the Republic of Indonesia or other officer appointed by the police chief of the Republic of Indonesia. Article 26 paragraph (2): examination of the child of the victim or child of the witness shall be conducted by the investigator as referred to in paragraph (1). Article 26 paragraph (3) requirements to be determined as investigator as referred to in paragraph (1) include:

a. Has experienced as an investigator

b. Has interest, attention. Dedication and understanding of the child's problem or

c. Have followed technical about juvenile justice

Article 26 paragraph (4) in the absence of an investigator who meets the requirements as referred to in paragraph (3) the task of investigation shall be carried out by an investigator conducting an investigation of a criminal act committed by an adult

Essential justice is the value that suits humanity, civilization and propriety. Every humanitarian value of civilization and propriety. Any humanitarian value. Civilization and propriety in accordance with the circumstances, where the environment and the time the people concerned live perceived members of the community is really right and fair. Where to strive for a terwujutnya something that is based in accordance with justice in this case investigators seek advice and considerations or suggestions from community counselors. Article 27 of Law Number. 11 of 2012:

Paragraph (1)

In conducting an investigation of a child's case, the investigator shall require consideration or 
advice from a community counselor after a crime is reported or reported.

Paragraph (2)

In conducting an investigation of a child's case, the investigator shall require consideration or advice from a psychologist, psychiatrist, religious leader, professional social worker or social welfare worker and other experts.

Paragraph (3)

In the case of conducting an examination of the child Victim and child Witnesses Investigators must request a social report from a professional social worker or Social Welfare Worker after the crime is reported or complained

In the event that the investigator will make an attempt of the Article 29 Diversy to mention:

Paragraph (1)

The Investigator shall seek Diversi within 7 (seven) days after the investigation commences.

Paragraph (2)

The process of diversion as referred to in paragraph (1) shall be held no later than 30 (thirty) days after the commencement of the diversion

Paragraph (3)

In the event that the Diversi Process reaches an agreement the investigator submits the version of the divergence event along with the diversion version agreement to the head of the district court to be established

Paragraph (4)

In the event of a failed version the investigator is obliged to continue the investigation and delegate the case to the public prosecutor by enclosing the divergence report and the community research report.

Based on the description and discussion related to the action that can be done by the investigator on the child of the Trafficking Actors in Law Number 11 Year 2012 is to keep conducting an investigation, because it is a dilemma if the investigator stops the investigation if it has proven to have been a crime and the perpetrator has been arrested. As it is known that the authority to set aside the criminal case itself is known as the embodiment of the principle of opportunity which is only owned by the Attorney General.

In practice, even in police investigation level, it is often confronted with formal criminal procedure if they want to override a criminal case, the discretion possessed by the police does not cover its authority to judge a case to be continued or terminated, the dosage is limited to sufficient evidence of crime. If there is evidence of a criminal offense, the police will continue to pursue the matter.

Therefore, it is necessary to encourage a more humane approach to criminal justice management, emphasizing and prioritizing restorative justice rather than formal legalistic considerations .Former Chief Justice Bagir Manan once wrote that barriers in peace-building between victims and perpetrators often stem from a highly formalistic law enforcement attitude by saying the legal process will continue despite peace, the unlawful nature will not be erased due to peace. According to him, is there still a goal of punishment that has not been reached if the parties have made peace with each other? The purpose of law enforcement is 
not to apply the law, but to achieve order, peace, tranquility, in a harmonious and just society order.

\section{B. Policy and Implementation of Law Number 11 Year 2012 Related to Sanction and action of Trafficking Trafficker Children}

Criminal policy in combating child trafficking It can be interpreted as the term "policy" and taken from the term "Policy" or "Politiek" starting from these two foreign terms, the term criminal law policy can also be referred to as "Criminal Political Law. "In criminal law politics is often known by various terms such as "Penal Policy", "Criminal Law Policy", or "Strafrechtspolitiek". The terminology can be used as general principles that serve to direct governance (in the broad sense), to manage, organize, or resolve public affairs, and the problems of society or the field of legislative drafting. According to Prof. Sudarto Political Law is:

1) Attempts to bring about a good order according to circumstances and situations at a time.

2) The policy of a country through the competent bodies to establish the desired rules can be used to express what is contained in society in order to achieve what is desired.

Meanwhile, according to A. Muller in Strafrechtspolitiek determined policy lines about:

1) How far the applicable criminal law provisions need to be improved.

2) What can be done to prevent a crime.

3) The manner in which investigations, prosecutions, judicial proceedings, and criminal executions should take place.

In relation to the use of penal facilities and penalties, especially for child trafficking policies, the conditions are no different. the use of Non- penal means has a larger portion than the use of penal means. Means that there is a need in the context of the crime, which is oriented to achieving understanding of the factors conducive causes of child trafficking (No. Krimo factor gene).Factor of crime Number of logic occupies an important position to understand the nature and background of the occurrence of child trafficking, as well as tracing and finding Non-penal means.

Based on the above dimensions, criminal law policy is essentially an attempt to realize the legislation to conform to the situation at a certain time (Ius Constitutum) and the future (IUS Constituendum) its logical consequence, criminal law policy identical to "Penal Reform" in the narrow sense. Because some of the criminal law system consists of cultural (cultural), structure (structual), and substance (substantive) law.

From the description above that crime prevention efforts are pursued by a policy approach in the sense that:

1) The existence of integrity (intergritas) between criminal politics and social politics.

2) There is integrity between crime prevention efforts with "Penal" and "Non Penal".

Two central problems in criminal policy by using penal means (penal law) is the problem of determination:

a. What actions should be criminalized and

b. What witness should be used or imposed on the offender. 
Analyzing these two (2) central problems, can not be separated from the intergal conception of criminal policy with social policy or national development policy. This means that the solution of the above problems must also be directed towards achieving certain goals of established social and political policy. Regarding the issues of acts categorized as "criminal acts" of child trafficking, based on Law Number .21 of 2007 on combating trafficking in persons, contains several elements as follows:

1) The existence of cross-action against people, namely:

recruitment, transportation, shelter, transfer or acceptance. The perpetrators conducted within the territory of Indonesia but also conducted between countries. Where the act of crossing the person, carried out by the perpetrator, by recruiting potential victims, to the shelter, where they will be employed.

2) The existence or purpose of action, namely: human exploitation. The purpose of trafficking in persons especially in children who are victims is to exploit the victims. Regarding the notion of exploitation seen in Article 1 paragraph 7 of the Law against the criminal acts of trafficking in persons. Namely: Exploitation is an act with or without the consent of the victim which includes but is not limited to prostitution, forced labor or services, slavery or similar practices of slavery, oppression, extortion, physical, sexual, reproductive organs or unlawfully removing or transplanting organs and / or body tissue or utilize the power or ability of someone by other parties to get both material and immaterial benefits.

3) Existence of prohibited mode of action, namely:

Threats, violence, abduction, capture, fraud, fraud, abuse, or vulnerable positions, debt bondage or payment or benefit, with the consent of the person in charge of the person, which creates fear, poses a danger to the life or body so as to place the person is in danger.

Based on the above formulation, then an act can be regarded as a crime of human trafficking, especially in relation to trafficking of children, if it has fulfilled the elements contained in Law Number .21 of 2007 on the eradication of criminal acts of trafficking in persons.

Law Number 21 Year 2007 Concerning the eradication of criminal acts of trafficking in persons, having a witness who explicitly regulates the traffickers of children. Under this law, it is argued that the perpetrator who commits a recruitment activity, by inviting, collecting and separating a person from his or her family including, any violation committed by an individual, a corporation, or an organizer of the state itself may be rewarded with a sentence of a minimum of 3 three years and a maximum of 15 years and a fine of at least $\mathrm{Rp}$ $120,000,000.00$ (one hundred and twenty million rupiah) and a maximum of $\mathrm{Rp}$ $600,000,000.00$ (six hundred million rupiah) in accordance with the provisions of Article 2 of Law Number 21 Year 2007.

According to Ninik Suparni the expert of Criminal Law in Indonesia, criminalization is defined as "the process of establishing an act as a criminal act." This process concludes with the formation of a law in which the act is threatened with a criminal witness. To criminalize Child Trafficking, it is necessary to pay attention to several aspects, according to Prof. Sudarto in the face of the central problem of criminalization in essence should note the following aspects: 
1) The use of criminal law should pay attention to the national development objective of realizing a just and prosperous, equitable, spiritual society for the achievement of community welfare.

2) Community-tackled actions are actions that bring harm (material and spiritual) to the people.

3) The use of criminal law should also pay attention to the principle of cost and yield. ( cost-benefit-principle).

4) The use of criminal law should also take into account the capacity of the workforce of law enforcement agencies ie do not exceed the task burden.

Thus, efforts to overcome crime in general can be divided into 2 "Penal" which is more focused on the nature of "Repressive" (Oppression, Eradication, Crushing) after the crime occurred. While the path " Non Penal" is more focused on the nature of "Preventif" (Prevention, Penangkalan, Control) before the crime occurred. Logical consequences on the other hand penal facilities have weakness / limitations in terms of the occurrence of crime. According to Barda Nawawi Arief weakness (Negative sides) include:

a. The dogmatic / idealistic criminal witnesses are the sharpest or most violent types of witnesses. (therefore referred to as ultimum remedium )

b. Functionally / pragmatically, operationalization and its application require various support facilities. (among other things: various organic laws, implementing agencies / apparatus and more demanding "high cost").

c. Witness criminal law is a "remedium" containing contradictory / paradoxical properties that contain elements or negative side effects

d. The use of criminal law in the fight against crime is merely a "kurieren am sympton" (treating or curing symptoms) so criminal law is a "symbiotic treatment" and not a "causative treatment" for such complex criminal causes beyond the reach of criminal law.

e. Criminal law or witness is a small part (subsystem) of social control means that is not possible to overcome the problem of crime as a very complex humanitarian and social problems. (as a socio-psychological, socio-political, socio-economic, socio-cultural and so on).

f. The punishment system is fragmentary and individual / personal, not structural or functional.

g. Criminal effectiveness is still dependent on many factors and is therefore often at issue.

Furthermore, criminal arrangements in the effort to crack down, trafficking perpetrators in the Criminal Code at this time, considered very less effective to eradicate or prevent trafficking cases are increasing. Where it is seen in Article 297 of the Criminal Code it is said that "Trafficking in Women and Trafficking of Adult Boys shall be punishable by imprisonment of up to six years".

Based on the understanding of Article 297 of the Criminal Code above, it can be seen that in the provision of Article 297 of the Criminal Code, threats against trafficking traffickers whose victims are women and boys under age are threatened with imprisonment of 6 (six) 
years. Based on this understanding, then in cracking down on traffickers, in general, the victims are girls under age, it is considered less able to ensnare the perpetrator. This is because, Article in the Criminal Code at the time, can not reach the substance of transnational crime and organized crime.

The Criminal Code (KUHP) law, in addition to being unable to reach the substance of crime, child trafficking, the Criminal Code also does not state the definition of child trafficking. In addition to the provisions mentioned above, Article 297 of the Criminal Code also does not regulate the procedures for trafficking in children, and what actions can be categorized as trafficking of children.

Based on the shortcomings contained in the Criminal Code, a special government regulation has been set up regarding the regulation of criminal sanctions against child trafficking, namely Law Number .21 of 2007 on the eradication of criminal acts of trafficking in persons. Where, current legislation, far to provide strict sanctions to child trafficking (child trafficking). Arrangement of sanctions against child traffickers in Article 2 of Law Number .21 of 2007 stated that:

Article 2 Paragraph (1) Any person hiring, transporting, sheltering, shipping, transferring, or receiving a person with threats of violence, use of force, abduction, capture, forgery, fraud, abuse of power or vulnerable positions, debt bondage or paying or the benefit of obtaining the consent of a person in control of another person for the purpose of exploiting that person in the territory of the Republic of Indonesia shall be subject to imprisonment of a minimum of 3 (three) years and a maximum of 15 (fifteen) years and a fine of at least Rp 120 (One hundred twenty million rupiah) and at most Rp600,000,000.00 (six hundred million rupiah).(2) If the acts as referred to in paragraph (1) result in the exploitation of persons, then the offender shall be punished with the same punishment as referred to in paragraph (1).

Judging from the setting of criminal sanctions against child traffickers, in Law Number .Law No. 21 of 2007 concerning the eradication of criminal acts of trafficking in persons, the threat to child traffickers, the shortest of which is between the 3 (three) years the longest is 15 ( fifteen) years imprisonment. Based on the formulation of Article above, it appears that, Law Number .21 of 2007, on the eradication of criminal acts of trafficking in persons, has a severe sanctions threat, in cracking down on child traffickers.

Law Number 21 of 2007 concerning the eradication of trafficking in persons, in relation to the regulation of sanctions against child traffickers, also poses a threat to the perpetrator, who trafficked the child, to be exploited. This can be seen in Article 6 of Law Number 21 Year 2007:

Any person who sends the child in or out of the country in any way that causes the child to be exploited shall be punished with imprisonment of a minimum of 3 (three) years and a maximum of 15 (fifteen) years and a fine of at least Rp120,000,000, 00 (one hundred twenty million rupiah) and at most Rp600.000.000,00 (six hundred million rupiah).

Besides the threat of sanctioning the perpetrators of trafficking, in this case, the perpetrator who trafficked the person, and the victim involves a minor, may also be added $1 / 3$ of the threat of punishment. Related to the above, Law Number .21 of 2007 on the eradication of criminal acts of trafficking in persons, much more has the specificity of sanctions, in 
providing threats to child traffickers. Specificity of sanction in Law Number .21 of 2007 in addition to containing the notion of trafficking in persons, is also more threatening sanctions are much more severe, to the perpetrators of trafficking and also accompanied by high fines.

Criminal derives from the word "Straf" (Dutch) which is called by the term of punishment. The criminal term is more appropriate than the term of punishment because the punishment is commonly a part of the translation of the criminal "Recht" defined as an affliction deliberately imposed or granted by the state to a person or persons as a result of law or (witness) to him for an act which has violated the legal prohibition the criminal is referred to as a criminal offense (straafbaarfeit) where the purpose of criminal law is to achieve order.

According to Sudarto, the criminal witness is a "deliberate misery to a person who commits an act that meets certain conditions." Furthermore, Sudarto also explained that the criminal witness is retaliation against the mistake of the maker, while the action is for the protection of society and for the guidance or maintenance of the maker.

A child who is 12 (twelve) years old although a criminal offense can not be imposed on a child trial. Such matters shall be based on sociological, psychological and paedagogical considerations that, a child of 12 (twelve) years of age and committing a crime shall not be subject to a criminal witness or action sanction. To determine whether to the child will be imposed a criminal or an act, the judge considers the severity of his or her crime committed. In addition, the child's condition, the state of the parents or guardian or foster parents relationship between family members and circumstances.

According to Law No. 11 of 2012 on Child Criminal Justice System Article 69 states:

Paragraph (1): The child shall only be subject to criminal or subject to action under the provisions of this Act

Paragraph (2): Children not yet 14 (fourteen) years of age may be subject to action only.

Criminal is a punishment imposed on a person who is proven legally and convincingly of committing a crime. Under the terms of Article 10 of the Criminal Code, the penalty consists of substantial punishment and additional penalties. The main sentences consist of death penalty, imprisonment which can be life sentence and temporary punishment, imprisonment and fine.

Regarding the issues concerning acts included in the trafficking of children, if we compare between the Criminal Code, Law Number .21 of 2007 on the eradication of criminal acts of trafficking in persons and Law Number 11 Year 2012, it is apparent that: in the KUHP is not regulated on the acts of child trafficking. Meanwhile, Law Number .21 of 2007, only regulates the means by which the perpetrator trades the victim, and the child's own trade objective. But there is no mention of the type of witnesses or actions related to restoractive justice in which, the perpetrator is a child. therefore, Law No. 11 of 2012 on the Child Criminal Justice System used to create Restorative Justice.

\section{Conclusion}

Based on the above discussion, it can be concluded that:

1). The forced attempts by the investigator to the child of Trafficking in relation to the concept of restroactive justice by conducting an investigation because the investigator can not rule out a case that has been proven to commit a crime and known to the perpetrator. 
Nevertheless, the maximum effort of handling child offenders in non-litigation cases is preferred by looking at the nature of the child and Non penal sanction is more appropriate for the child of the offender.

2). The action that can be done by the investigator on the child of the Trafficking Trafficker in Law Number 11 Year 2012, to substitute restitution, and the return to the parent / guardian is a matter that is deemed appropriate, since the investigator has no authority to override the case, even in conducting the investigation with consideration of more emphasis and prioritizing restorative justice approach than formal legalistic consideration.

\section{References}

Abintoro, P. (2013). Reform of the Criminal Justice System. Laksbang Grafika, Yogyakarta, p. 161.

Arief, G. (1993). Problems of Crime Victims (Sekkarangan). Akademika Pressindo, Jakarta.

Atmasasmita, R. (1983). Problema Delinquency of Youth Children (juridical socio creamNomorlogis). Armico, Bandung.

Barda, N. A. (2002). Culmination of Criminal Law Policy. PT Citra Aditnya Bakti, Bandung.

Barda, N. A. (2002). Cultivation Bureau of Criminal Law Policy (hereinafter abbreviated as BardaNawawi Arief II). Cet II, PT Citra Aditnya, Bakti.

Chazawi, A. (2005). Criminal Law Lessons I (Stelsel Pidana, Criminal Acts, Theory of Penalties and the limits of the law). PT Raja Grafindo, Jakarta

Dikdik, M. A. M., \& Elissatris, G. (2007). Urgency Protection of Victims of Crime Between Number and Reality, Raja Grafindo Persada, Jakarta.

Gosita, A. (1985). Child Protection Issues. Akedemia Pressindo, Jakarta.

Gultom, M. (2008). Legal Protection Against Children in the Juvenile Justice System in Indonesia, Cet I, PT Refika Aditama, Bandung.

Irwanto. (2001). Child Trafficking in Indonesia. Progressia, IV(02).

Lilik, M. (2007). Compilation of Criminal Law in the Theoritical and Judicial Practice Practices, Mandar Maju, Bandung, p. 63.

Marlina. (2012). Child Criminal Justice in Indonesia The Development of Diversi Concept, PT Refika Aditama, Bandung.

Muhammad, R. (2013). Indonesian Criminal Justice System, UII Press Yogyakarta.

Mulyadi, L. (2004). Kapita Selekta Penal Code KrimiNomorlogi and Viktuologi, Djambatan, Jakarta.

Mulyadi, L. (2007). Compilation Mandar Maju, Bandung Criminal Law in Theoretical and Judicial Practice Presidency, Mandar Maju, Jakarta.

Ninik, S. (1996). The Existence of Criminal Fines in the Penal System and Penalties, Sinar Grafika, Jakarta, p. 15.

Rini, M. (2014). Trafficking Trafficking Women and Children A Problem and Handling Retrieved from http: //www.Pemantau.com

Sholehuddin, M. (2003). Witness System in Criminal Law, PT Raja Grafindo Persada Jakarta.

Sudarto. (1981). Law and Criminal Law, Alumni, Bandung. 
Valentina, R. S., \& Ellin, R. (2007). Eradicating Trafficcking Women and Children, Mandar Maju, Bandung.

Wadong, M. H. (2000). Introduction to Advocacy and Child Protection Law, P T. Gramedia widiasarana Indonesia, Jakarta.

Yahya, H. (1993). Several Review of the Court System and Settlement of Disputes, Citra Aditya Bakti, Bandung, p. 89.

Yesmil, A., \& Adang (2009). Criminal Justice System Concepts, Components, and Implementation in law enforcement in Indonesia, Widya Padjajaran, Bandung.

Yesmil, A., \& Adang, S. H. (2011). Criminal Justice System Concepts, Components, and Its Implementation in Law Enforcement in Indonesia, Widya Padjadjaran, Bandung, p. 283.

\section{Copyright Disclaimer}

Copyright for this article is retained by the author(s), with first publication rights granted to the journal.

This is an open-access article distributed under the terms and conditions of the Creative Commons Attribution license (http://creativecommons.org/licenses/by/3.0/). 